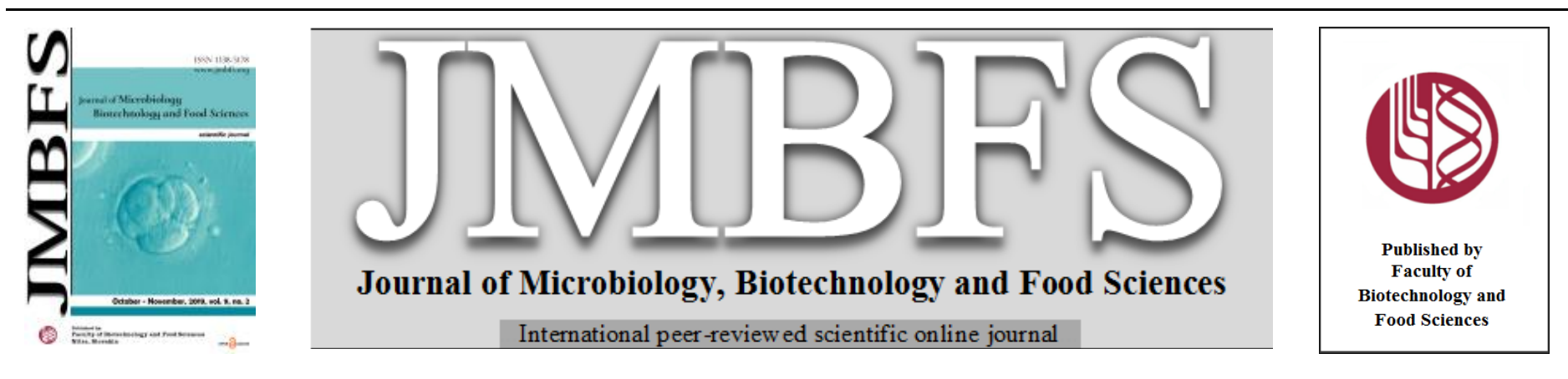

\title{
STUDIES ON SOME PLANT EXTRACTS AS ANTIMICROBIALS AND FOOD PRESERVATIVES
}

\author{
Dawoud Ezz Eldien ${ }^{1,}$ Gihan Mohammed El Moghazy² and Hala Nader Fahmy ${ }^{*}$ \\ Address(es): \\ ${ }^{1}$ Faculty of Science, Cairo University, Giza, Egypt, Postal code: 12613, Phone number: 00201027980781. \\ ${ }^{2}$ Regional Center for Food and Feed, Agricultural Research Center, Giza, Egypt, Postal code: 12619, Phone number: 00201222331390.
}

*Corresponding author: hnader80@yahoo.com

doi: 10.15414/jmbfs.2020.9.4.790-798

ARTICLE INFO

Received 17. 2. 2019

Revised 6. 9. 2019

Accepted 24. 9. 2019

Published 3. 2. 2020

Regular article OPEN $\partial_{\text {ACCESS }}$

\begin{abstract}
This study was conducted to detect the effect of some essential oil (EOs) extracts (Thyme, Oregano, and Menthol) as natural food preservatives against some food-borne pathogens (salmonella Typhimurium and E. coli, Staphylococcus aureus, Bacillus cereus and listeria monocytogens). The selected extracts were in concentrations ranging from $0.01 \%$ to $0.8 \% \mathrm{v} / \mathrm{v}$ using broth dilution technique. The Obtained results revealed that the minimum inhibitory concentrations (MICs) of the used extracts $0.3 \%, 0.1 \%$ and $0.8 \%$ for Thyme, Oregano, and Menthol, respectively, depended on the concentrations which inhibited Bacillus cereus as it is considered the most resistant Gram-positive spore-forming strain. Studying the mode of action of the used EOs against Salmonella sp. were performed using Transmission Electron Microscope (TEM) which indicated cell wall and plasma membrane damage. Also, the obtained MICs of EOs were used in preparation of luncheon to study the possibility of its usage instead of or together with the chemicals used for preservation during luncheon processing. The obtained results showed that, in luncheon processing, thyme extract has the same preservative effect as sodium nitrite $(125 \mathrm{ppm})$ when it is used as the lonely preservative substance while using the obtained MICs of the used EO with 50 ppm of sodium nitrite had a reliable preserving effect in luncheon process.
\end{abstract}

Keywords: Thyme, Oregano, Menthol, Minimum Inhibitory Concentration, Food poisoning, Salmonella, E. coli, Staphylococcus aureus, Bacillus cereus, Listeria monocytogenes, TEM, Preservatives

\section{INTRODUCTION}

Food-borne disease is caused by infectious or toxic agents that enter the body by ingestion of contaminated food and/or water. It causes health problems in many developed and developing countries (WHO, 2007). The main causative agents of food poisoning are bacteria (66\%) and viruses (4\%). Food-borne illness results from either intoxication (which occurs when toxins are produced by the pathogens inters gastrointestinal tract) or infection (caused by ingestion of food containing pathogen itself). Botulism, Clostridium perfringens gastroenteritis, $E$. coli infection, Salmonellosis and staphylococcal food poisoning are the major food illnesses caused by bacteria. The most common clinical symptoms of foodborne illnesses are diarrhea, vomiting, abdominal cramps, headache and nausea (Mekonnen \& Sisay, 2015).

Several approaches have been employed to find out good preservatives that cause inhibiting, retarding or arresting food fermentation, acidification, microbial contamination, and decomposition. Preservatives are important commonly used substances that efficiently accomplish these targets. Different sources of preservatives include natural preservatives (salt, sugar, vinegar, syrup, spices, honey and edible oil) and chemical and synthetic substances (benzoates, sorbates, nitrites, nitrates, sulfites, glutamates and glycerides)(Anand \& Sati, 2013).

Either natural or synthetic preservatives are categorized into 3 types: 1) Antimicrobials, which destroy or delay the growth of microorganisms, 2) Antioxidants, which slow or stop the breakdown of fats and oils in food that occurs in the presence of oxygen leading to rancidity and 3) Anti-enzymatic, which blocks the unwanted enzymatic processes(Anand \& Sati, 2013).

Many studies have shown the side effects of using sulfites as a chemical preservative that included headaches, palpitations, allergies, and, in many cases, cancer. Also, when Nitrates and Nitrites, which are used as preservatives in meat products, are consumed, they are converted into nitrous acid which is responsible for causing stomach cancer. Benzoates and Sorbates are used as antimicrobials in food and they have been suspected to cause allergies, asthma and skin rashes (Sharma, 2015). Hence, it was very important to find out safe, economic and available alternatives to provide the same preservative effect in different food categories.

Essential oils are plant extracts that perform antimicrobial and antioxidant activities. They are healthy and safe ingredients that can be obtained from a variety of plant materials and can do both, reducing the incidence of food-borne diseases and retarding lipid oxidation (Boskovic et al., 2015). These oils are made from very complex mixtures of mainly volatile molecules that are produced by the secondary metabolism of aromatic and medicinal plants. They may bring about their effect through disrupting the function of the bacterial cell wall through affecting their lipopolysaccharides content leading to an increase in the cell membrane permeability and Adenosine Tri Phosphate loss(Faleiro, 2011).

The aim of the present study was to investigate the antibacterial activity and effective concentrations of thyme, oregano and menthol oil extracts against Salmonella Typhimurium, E. coli, Staphylococcus aureus, Bacillus cereus and Listeria monocytogenes and to evaluate their mechanism of action through microscopic analysis using Transmission Electron Microscope. This study is also meant to estimate the effect of using the tested EOs on the shelf lifetime of Luncheon when partially or completely replacing the recommended concentration of sodium nitrite.

\section{MATERIALS AND METHODS}

\section{Bacterial strains}

Strains of Salmonella, Escherichia coli, Staphylococcus aureus, Bacillus cereus and Listeria monocytogenes were kindly isolated, identified and supplied by Food Safety laboratory, Regional Center for Food and Feed, and Agricultural Research Center, Egypt. The strains were maintained on slants of Nutrient Agar (NA) at $4^{\circ} \mathrm{C}$ in the laboratory. The microorganisms were cultured in Brain Heart Infusion broth and were incubated at $37^{\circ} \mathrm{C}$ for $24 \mathrm{~h}$.

\section{Essential oils (EOs)}

Oil extracts of Oregano, Thyme, and Menthol were kindly supplied by National Organization for Drug Control and Research (NODCAR), Giza, analyzed according to(Santana et al., 2013) by GC-MS/MS (Agilent Technologies 7890A), interfaced with a mass-selective detector (MSD Agilent 7000), and equipped with a polar Agilent HP-5ms (5\%-phenyl methyl poly siloxane). Capillary column 
(30m $\times 0.25 \mathrm{~mm}$ i.d. and $0.25 \mu \mathrm{m}$ film thickness) was used to estimate the abundance of its active ingredients, qualitatively.

\section{Determination of Minimum Inhibitory Concentration (MIC)}

Minimum inhibitory concentrations were determined according to Senhaji, Faid, \& Kalalou (2007). Briefly, the bacterial suspensions prepared from the overnight broth cultures were adjusted to the required microbial density (about 107 $\mathrm{CFU} / \mathrm{mL})$.

EOs were dissolved in dimethyl sulphoxide (DMSO) $(\mathrm{v} / \mathrm{v})$ in concentrations of $(0.03 \% 0.05 \%, 0.1 \%, 0.2 \%, 0.3 \%, 0.4 \%$ and $0.5 \%)$ and $(0.01,0.02,0.03 \%$, $0.05 \%, 0.1 \%, 0.2 \%, 0.3 \%, 0.4 \%$ and $0.5 \%)$ and $(0.03 \%, 0.05 \%, 0.1 \%, 0.2 \%$, $0.3 \%, 0.4 \%, 0.5 \%, 0.6 \%, 0.7 \%$ and $0.8 \%$ ) for Thyme, Oregano and Mentho respectively were prepared in sterile test tubes that contained Brain heart infusion broth after which $100 \mu \mathrm{L}$ suspension of the tested bacteria was added into the tube. The MIC was determined as the lowest concentration of EOs that demonstrated no visible growth in cultured tubes after $24 \mathrm{~h}$.

\section{Transmission Electron Microscope (TEM)}

In order to determine the cellular changes of the tested bacterial strains under test after exposure to the used concentrations of EOs TEM was used as reported by (Gao et al., 2011), as follows

1. Salmonella strain was inoculated in $100 \mathrm{ml} \mathrm{BHI} \mathrm{broth} \mathrm{which} \mathrm{then} \mathrm{was}$ divided into 4 equal volumes. One part was kept as control and the 3 other parts were inoculated each with concentration below that determined the MIC of each oil extract.

2. All suspensions were incubated at $37^{\circ} \mathrm{C}$ for $24 \mathrm{~h}$ and then centrifuged at $5,000 \times \mathrm{g}$ for $5 \mathrm{~min}$ at $4^{\circ} \mathrm{C}$.

3. The cells were washed three times with 0.1 M PBS (pH 7.4) for 15 min each and fixed in $2.5 \%(\mathrm{v} / \mathrm{v})$ Glutaraldehyde for $2 \mathrm{~h}$ at $4{ }^{\circ} \mathrm{C}$.

4. The cells were washed three times with 0.1 M PBS (pH 7.4) for 15 min each and fixed in $2.5 \%(\mathrm{v} / \mathrm{v})$ glutaraldehyde overnight at $4{ }^{\circ} \mathrm{C}$.

5. The cells were washed three times with 0.1 M PBS (pH 7.4) for 15 min each again, and post-fixed with $1 \%(\mathrm{w} / \mathrm{v})$ osmic acid for $2 \mathrm{~h}$ at room temperature, then washed three times with the same PBS.

6. The cells were dehydrated by a sequential graded ethanol $(30,50,70$, and $90 \%$ ) and then acetone (90 and 100\%) for 15 min each. After the dehydration, embedding medium was added into all samples.

7. Stained bacteria were viewed and photographed with (TEM EM 208S, Philips, USA) instrument.

\section{Estimation of the shelf lifetime of Luncheon as affected by MICs of EOs}

Beef samples were purchased from local market, minced and divided into 7 groups, each was $80 \mathrm{gm}$. Different Luncheon compositions were prepared by mixing the 7 groups with different ingredients (as illustrated in Table 1) according to Codex Alimentarius guidelines (Codex, 1981). The effective MICs $(0.3 \%, 0.1 \%$ and $0.8 \%$ from Thyme, Oregano, and Menthol, respectively) were added as mentioned in (Table 1).

Table 1 Preparation of luncheon according to codex 1981 Treatments

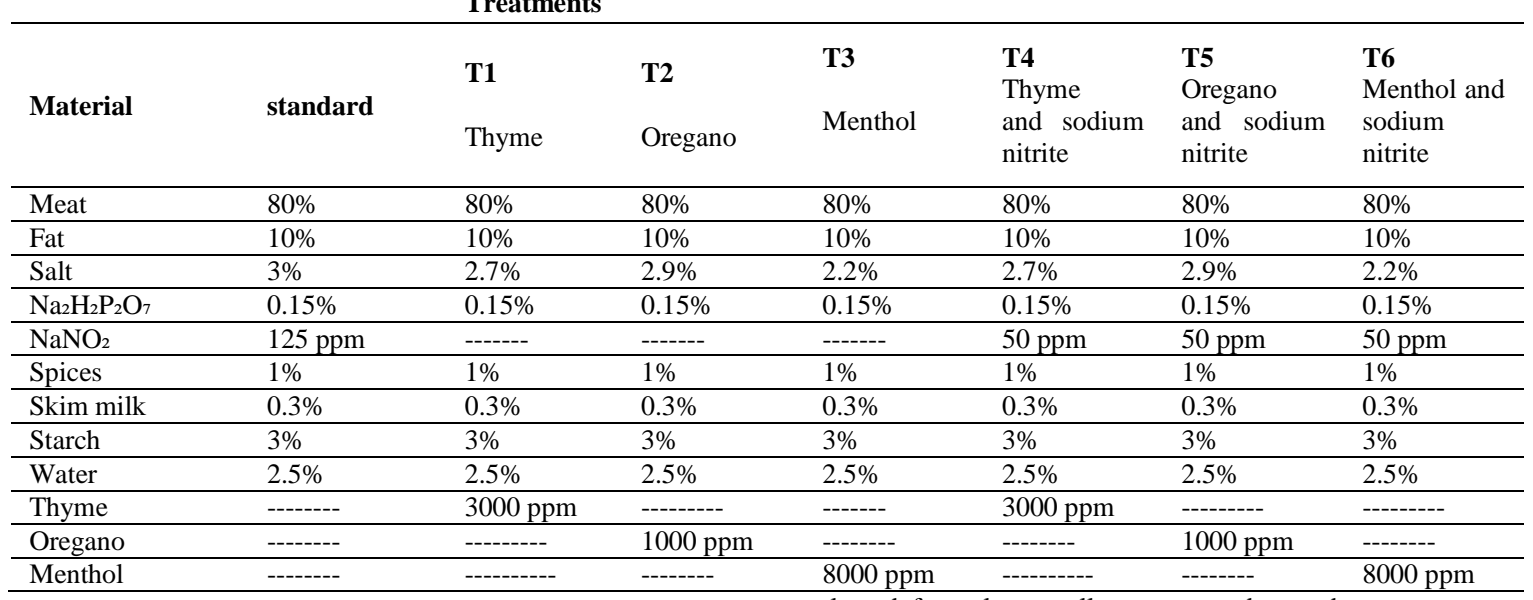

evaluated for color, smell, texture, and taste by ten persons and recorded in

A subsample representing the unprocessed product was taken to estimate its microbial content after which the mixtures were packaged in thermal transparent bags, stretched well and warped with aluminum foil, and then Processed in boiling water for $30 \mathrm{~min}$ (Mahmoud et al., 2016).

Subsamples were taken after processing with time intervals of $0,1,3,5,7,9$ and 14 days. Determination of Total Bacterial count (TPC), Total Coliform count (TCC), Faecal Coliform count (FCC), Staphylococcus count, Bacillus cereus count, Salmonella count, Total Fungal Count (TFC) including Total Yeast Count (TYC) were performed according to (NMKL, 2013), (NMKL, 2004), (NMKL 2005b)(NMKL, 2009), (NMKL, 2010), (Gantois et al., 2008) and (NMKL, 2005a), respectively

Panel test was performed according to (Alvi, Rizvi, \& Hadi, 1986) for subjective evaluation of luncheon sensory quality. Luncheon was subsampled into seven groups according to the previous parameters and cut into small parts, then Figure (8).

Statistical analysis was performed according to (SPSS, ver.21).

\section{RESULTS}

The data in Table (2) showed the active ingredients in the used 3 oils. It is clear from the obtained data that Thymol and Carvacrol are the major ingredients in both Thyme and Oregano as they give the largest peak area when qualitatively analyzed by GC-MS/MS. The peak areas of Thymol were 13.7 and 3.3 in Thyme and Oregano while those of Carvacrol were 23.2 and 16, respectively. In case of Menthol, the most abundant active ingredients were M-Isopropyl- $\alpha$-methy styrene which gave the largest peak area 13.4 when compared to the rest of the obtained active ingredients.

Table 2 Chemical composition and peak areas of essential oils analyzed by GC Mass

\begin{tabular}{|c|c|c|c|}
\hline Chemical compound & $\begin{array}{l}\text { Thyme } \\
\text { (peak area) }\end{array}$ & $\begin{array}{l}\text { Oregano } \\
\text { (peak area) }\end{array}$ & $\begin{array}{l}\text { Menthol } \\
\text { (peak area) }\end{array}$ \\
\hline (-)-Carvone & ------- & ---------- & 4.56 \\
\hline (-)-Spathulenol & 0.9 & ---------- & ------- \\
\hline (E)-Sesquisabinene hydrate & --------- & ----------- & 1.06 \\
\hline 1,4-Dithiothreitol & 1.29 & ----------- & --------- \\
\hline 1-Heptatriacotanol & -------- & 0.26 & --------- \\
\hline 2-Allylphenol & 11.45 & --------- & --------- \\
\hline 2'-Hydroxy-2,4,5-trimethoxychalcone & 1.36 & --------- & ------- \\
\hline 2-tert-Butyl-4-methyl-6-(1-methyl-1-phenylethyl)phenol & ------- & 0.33 & -------- \\
\hline 3,4,5-Trimethoxycinnamic acid & ------- & ------- & 0.27 \\
\hline 3,6,2',3'-Tetramethoxyflavone & 0.53 & -------- & ------- \\
\hline 3,7,3',4'-Tetrahydroxyflavone & ------- & 1.63 & ------- \\
\hline 3,7,8,4'-Tetramethoxyflavone & 0.93 & ------- & ------- \\
\hline 3,8-p-Menthadiene & 1.33 & $\begin{array}{ll}------ \\
\end{array}$ & ------- \\
\hline 3-Carene & 3.04 & -------- & ------- \\
\hline
\end{tabular}




\begin{tabular}{|c|c|c|c|}
\hline Chemical compound & $\begin{array}{l}\text { Thyme } \\
\text { (peak area) }\end{array}$ & $\begin{array}{l}\text { Oregano } \\
\text { (peak area) }\end{array}$ & $\begin{array}{l}\text { Menthol } \\
\text { (peak area) }\end{array}$ \\
\hline 4-Terpinenyl acetate & -------- & 0.69 & -------- \\
\hline $5 \beta, 7 \beta \mathrm{H}, 10 \alpha$-Eudesm-11-en-1 $\alpha$-ol & ---------- & -------- & 2.62 \\
\hline 6-Epishyobunone & ---------- & 1.34 & -------- \\
\hline 7,3',4',5'-Tetramethoxyflavanone & 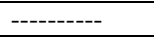 & 0.73 & 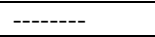 \\
\hline Acetic acid, methoxy- & ----------- & -------- & 0.51 \\
\hline Alloaromadendrene oxide-(1) & --------- & 0.53 & 0.84 \\
\hline Anisole, p-isopropyl- & 0.69 & ----- & ------ \\
\hline Ascaridole epoxide & ----- & 0.75 & ------- \\
\hline Ascaridole & ------- & ------- & 1.29 \\
\hline Astilbin & 0.53 & ------- & ----- \\
\hline Berbenone & ------ & ------- & 6.39 \\
\hline Calarene epoxide & ------- & 1.1 & ------- \\
\hline Camphene & ------- & 1.12 & ------- \\
\hline Carvacrol & 23.22 & 16.05 & -------- \\
\hline Caryophyllene oxide & ------- & ------- & 4.48 \\
\hline Caryophyllene & 1 & +------ & -------- \\
\hline Cedrenol & +----- & 2.96 & ------ \\
\hline Cedrol & ------- & 0.49 & ------- \\
\hline Cembrene & ------- & ------- & 0.74 \\
\hline Chamigren & ------ & 3.87 & -ב---- \\
\hline Chromon-6-ol, 5-bromo-3,4-dihydro-2,2,7-trimethyl- & ----- & 0.58 & ------ \\
\hline Cineole & -------- & ------- & 6.8 \\
\hline Cinnamaldehyde, $\alpha$-methyl- & ------- & ------- & 0.99 \\
\hline Cinnamic alcohol & +------ & 11.9 & ----- \\
\hline Cis-11-Eicosenoic acid & 0.67 & ------ & ----- \\
\hline Cis-Z- $\alpha$-Bisabolene epoxide & ------- & ------ & 0.54 \\
\hline Cis-Z- $\alpha$-Bisabolene epoxide & ----- & 7.86 & ------ \\
\hline Curcumol & ----- & ----- & 1.31 \\
\hline Epiglobulol & ------- & ------ & 0.78 \\
\hline Estragole & (----- & ------- & 2.71 \\
\hline Ethyl linalool & ------ & +------ & 1.49 \\
\hline Eucalyptol & -------- & 0.55 & ------ \\
\hline Farnesol & 0.56 & 0.32 & 0.26 \\
\hline Fenchene & 2.16 & ----- & ------ \\
\hline Genkwanin & ----- & 0.46 & ----- \\
\hline Geranyl- $\alpha$-terpinene & ------- & 1.51 & ------ \\
\hline Globulol & ----- & ------ & 0.64 \\
\hline Guaiol & ----- & ----- & 1.07 \\
\hline Isocaryophillene & ------ & 0.59 & ------ \\
\hline Isolongifolol & 0.92 & -------- & 1.22 \\
\hline Isomenthone & -------- & -------- & 6.98 \\
\hline Isopulegol & ------ & ------- & 6.69 \\
\hline Kaempferol-7-O-neohesperidoside & 1.87 & ------ & ----- \\
\hline Kaur-16-ene & ----- & 0.37 & $\begin{array}{ll}----- \\
\end{array}$ \\
\hline Lanceol, cis & 0.48 & ----- & ----- \\
\hline Ledol & +----- & ------- & 0.98 \\
\hline Limonen-6-ol, pivalate & $\begin{array}{ll}+--- \\
--\end{array}$ & 1.82 & $\begin{array}{ll}-{ }^{\prime} \\
-\cdots--\end{array}$ \\
\hline Limonene & 1.09 & ------ & ----- \\
\hline Linalool & 5.9 & 3.4 & ------- \\
\hline Linalyl acetate & 5.21 & 6.54 & -ב--- \\
\hline L-Menthone & - -------- & ----- & 6.55 \\
\hline Longipinocarveol, trans- & --------- & 1.06 & ------- \\
\hline Longiverbenone & ------- & 3.32 & ------- \\
\hline Lsopropyl acetate & |------ & ------ & 1.36 \\
\hline Methyl copalate & |------ & (------ & 1 \\
\hline M-Isopropyl- $\alpha$-methylstyrene & ------ & ------- & 13.41 \\
\hline Morin & ------- & 1.2 & \\
\hline Myrtenal & ------ & ------ & 3.48 \\
\hline Nerolidol & 0.42 & & \\
\hline Nordihydroguaiaretic acid & 2.43 & 0.9 & \\
\hline O-Cymene & - ----- & - ----- & 1.45 \\
\hline P-Camphorene & +----- & 1.03 & +----- \\
\hline p-Cymen-7-ol & ------ & 4.67 & ----- \\
\hline p-Cymene & 4.07 & ------ & $\begin{array}{ll}---- \\
-\end{array}$ \\
\hline Perilla aldehyde & $\begin{array}{ll}----- \\
\end{array}$ & $\begin{array}{ll}---- \\
\end{array}$ & 3.22 \\
\hline Phenol, 4,4'-methylenebis[2,6-dimethyl- & ------- & 1.15 & $\begin{array}{ll}---- \\
-1\end{array}$ \\
\hline Phenol, m-tert-butyl- & 0.36 & ----- & ----- \\
\hline Phenol, tetramethyl- & +---- & +---- & 1.77 \\
\hline
\end{tabular}


Continue Table 2 Chemical composition and peak areas of essential oils analyzed by GC Mass

\begin{tabular}{|c|c|c|c|}
\hline Chemical compound & $\begin{array}{l}\text { Thyme } \\
\text { (peak area) }\end{array}$ & $\begin{array}{l}\text { Oregano } \\
\text { (peak area) }\end{array}$ & $\begin{array}{l}\text { Menthol } \\
\text { (peak area) }\end{array}$ \\
\hline p-Mentha-1,5,8-triene & ----- & 2.31 & ----- \\
\hline P-Menthan-3-one & $\begin{array}{ll}------ \\
\end{array}$ & ------- & 2.02 \\
\hline Propanoic acid, 3-methoxy-, methyl ester & $\begin{array}{ll}----- \\
\end{array}$ & 0.37 & $\begin{array}{ll}----- \\
\end{array}$ \\
\hline Pseudolimonen & ------- & 2.78 & ------ \\
\hline Quercetin 3'-methyl ether & ------- & ------- & 0.29 \\
\hline Rimuen & $\begin{array}{ll}------ \\
\end{array}$ & 0.51 & \\
\hline Santalol, cis, $\alpha-$ & ------ & $\begin{array}{l}------ \\
--1\end{array}$ & 0.77 \\
\hline Sesquicineole & 0.59 & ------- & 0.53 \\
\hline Shyobunon & 0.84 & $\begin{array}{ll}------ \\
\end{array}$ & -------- \\
\hline Terpinen-4-ol & 1.45 & $\begin{array}{ll}------ \\
\end{array}$ & --------- \\
\hline Thujopsene & & $\begin{array}{ll}------ \\
\end{array}$ & 0.19 \\
\hline Thunbergene & 0.55 & $\begin{array}{ll}------ \\
\end{array}$ & --------- \\
\hline Thunbergol & ------ & 0.66 & -------- \\
\hline Thymol & 13.71 & 3.28 & -------- \\
\hline Trans-Geranylgeraniol & -------- & 0.68 & 0.46 \\
\hline Trans-Sabinene hydrate & --------- & $\begin{array}{ll}------- \\
\end{array}$ & 1.95 \\
\hline Trans- $\beta$-Ocimene & ------- & $\begin{array}{ll}------ \\
--1\end{array}$ & 1.11 \\
\hline Widdrol & ------- & - ------ & 0.41 \\
\hline$\alpha$ Isomethyl ionone & ------- & 1.18 & ------- \\
\hline$\alpha$-Campholenal & 0.48 & --------- & -------- \\
\hline$\alpha$-Himachalene & ------- & 0.36 & ------- \\
\hline$\alpha$-Ionene & ------- & $\begin{array}{ll}------ \\
\end{array}$ & 0.37 \\
\hline$\alpha$-Methylionol & 0.69 & ------- & ------- \\
\hline$\alpha$-Patchoulene & 0.85 & ------- & -------- \\
\hline$\alpha$-Phellandrene & 0.65 & ------- & -------- \\
\hline$\alpha$-Pinene & --------- & 2.27 & -------- \\
\hline$\alpha$-Terpinyl propionate & 5.14 & $\begin{array}{ll}------ \\
\end{array}$ & -------- \\
\hline$\beta$-Acoradienol & --------- & -------- & 0.7 \\
\hline$\beta$-Eudesmol & ------- & ----------- & 1.8 \\
\hline$\beta$-Guaiene & -------- & 0.58 & --------- \\
\hline$\beta$-Longipinene & --------- & 0.86 & --------- \\
\hline$\beta$-Myrcene & --------- & --------- & 0.59 \\
\hline$\beta$-Ocimene & -------- & 2.78 & ------- \\
\hline$\beta$-Pinene & ------- & --------- & 0.46 \\
\hline$\beta$-Santalol & 1.48 & --------- & -------- \\
\hline$\beta$-Spathulenol & - ------ & 1.14 & -------- \\
\hline$\gamma$-Gurjunenepoxide-(1) & --------- & 0.52 & ---------- \\
\hline$\gamma$-Terpinene & 0.91 & +------ & -------- \\
\hline
\end{tabular}

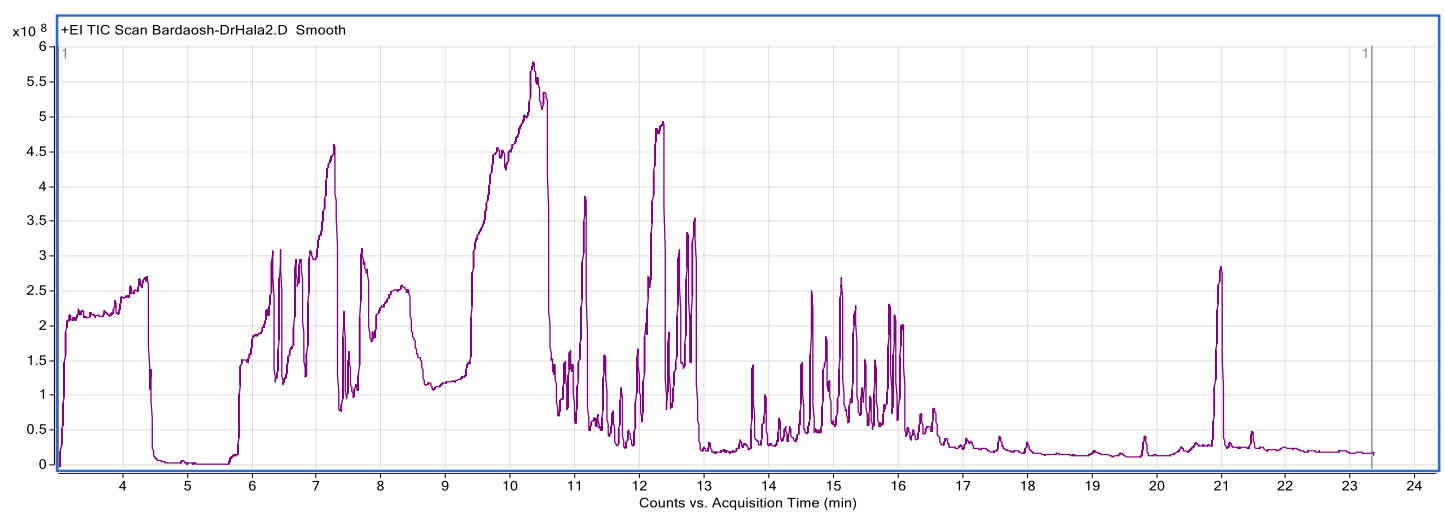

Figure 1 Graph of active ingredients of Oregano oil by GC Mass

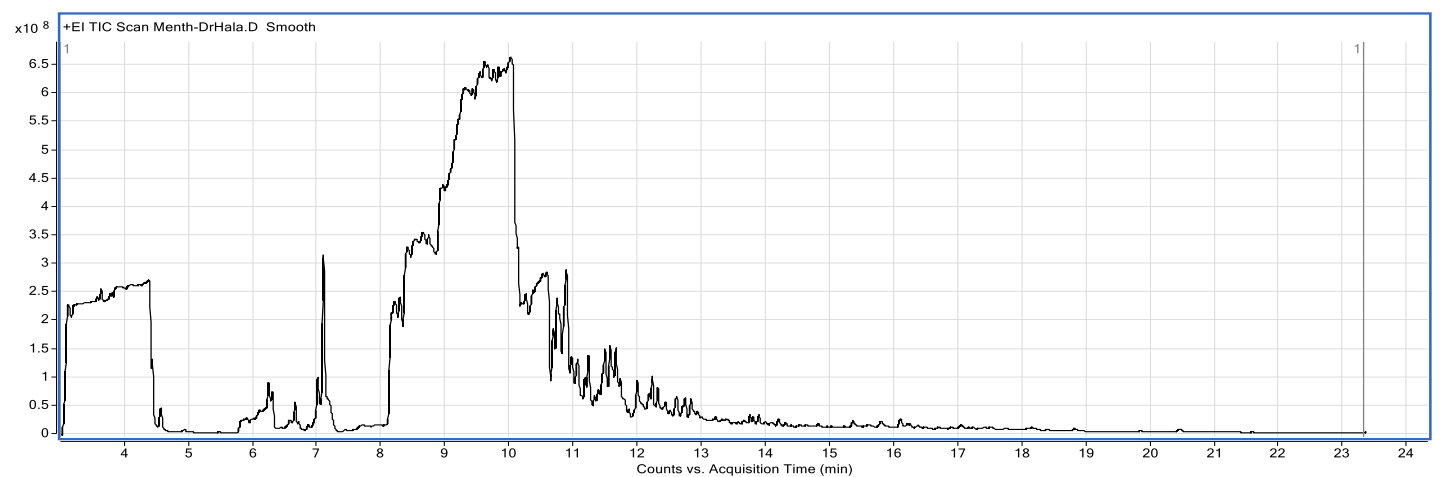

Figure 2 Graph of active ingredients of Menthol oil by GC Mass 


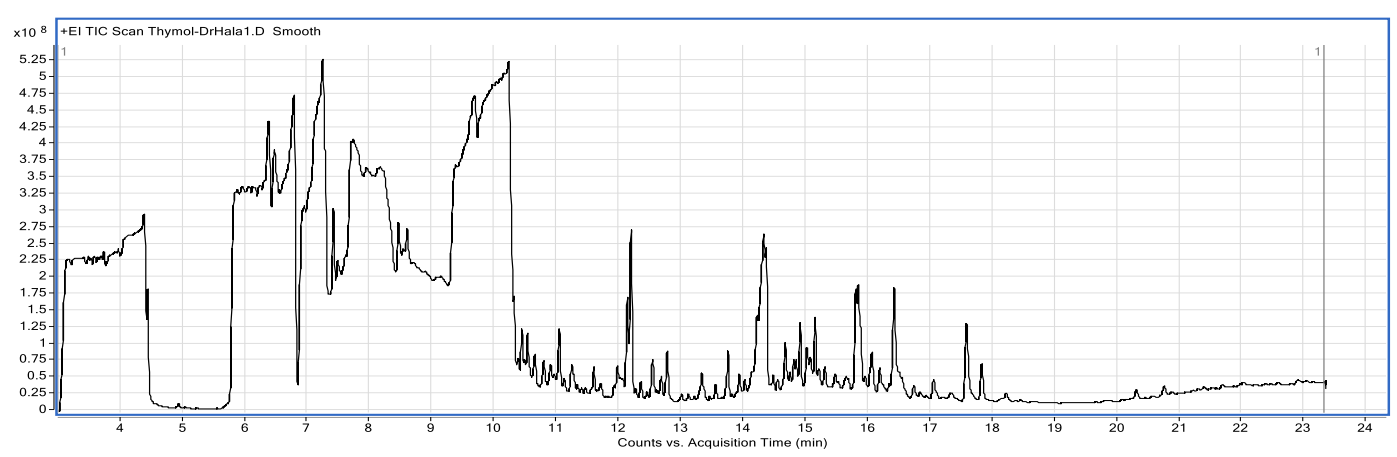

Figure 3 Graph of active ingredients of Thyme oil by GC Mass

Results from Table (3) illustrated that the MICs of Thyme oil extract against E.Coli, Staphylococcus spp., Salmonella spp., Listeria monocytogenes and Bacillus cereus were $0.05,0.2,0.1,0.2$ and 0.3 , respectively. The same effect was obtained using other oil extracts but with different concentrations $(0.03,0.1$, $0.1,0.1$ and 0.1 for oregano and $0.3,0.5,0.3$, and 0.8 for Menthol (Table $4 \& 5$ ).
N.B. The symbol "+" indicates the positive effect as inhibitory concentration, the symbol "." indicates the negative effect as inhibitory concentration and the abbreviation "NT" indicates that this item was not tested.

Table 3 Results of Minimum inhibitory concentration (MIC) of Thyme against some Gram +ve and Gram -ve bacteria

\begin{tabular}{llllllll}
\hline Essential oil & Thyme & & & & & & \\
\hline \multicolumn{1}{l}{ Conc. } & & & & & & \\
\hline Tested M.O. & $\mathbf{0 . 0 3 \%}$ & $\mathbf{0 , 0 5 \%}$ & $\mathbf{0 . 1 \%}$ & $\mathbf{0 . 2 \%}$ & $\mathbf{0 . 3 \%}$ & $\mathbf{0 . 4 \%}$ & $\mathbf{0 . 5 \%}$ \\
\hline E.coli O157:H7 & - & + & + & + & + & + & + \\
\hline Staphylococcus & - & - & - & + & + & + & + \\
\hline Salmonella & - & - & + & + & + & + & + \\
\hline Listeria monocytogens & - & - & - & + & + & + & + \\
\hline Bacillus cereus & - & - & - & - & + & + & + \\
\hline
\end{tabular}

Table 4 Results of Minimum inhibitory concentration (MIC) of Oregano against some Gram +ve and Gram -ve bacteria

\begin{tabular}{|c|c|c|c|c|c|c|c|c|c|}
\hline \multirow{2}{*}{ Essential oil } & \multicolumn{9}{|c|}{ Oregano } \\
\hline & Conc. & & & & & & & & \\
\hline Tested Mo. & $0.01 \%$ & $0.02 \%$ & $0.03 \%$ & $0.05 \%$ & $0.1 \%$ & $0.2 \%$ & $0.3 \%$ & $0.4 \%$ & $0.5 \%$ \\
\hline E.Coli O157:H7 & - & - & + & + & + & + & + & + & + \\
\hline Staphylococcus & NT & NT & - & - & + & + & + & + & + \\
\hline Salmonella & NT & NT & - & - & + & + & + & + & + \\
\hline Listeria monocytogens & NT & NT & - & - & + & + & + & + & + \\
\hline Bacillus cereus & NT & NT & - & - & + & + & + & + & + \\
\hline
\end{tabular}

Table 5 Results of Minimum inhibitory concentration (MIC) of Menthol against some Gram +ve and Gram -ve bacteria

\begin{tabular}{|c|c|c|c|c|c|c|c|c|c|c|}
\hline \multirow{2}{*}{ Essential oil } & \multicolumn{10}{|c|}{ Menthol } \\
\hline & Conc. & & & & & & & & & \\
\hline Tested Mo. & $0.03 \%$ & $0.05 \%$ & $0.1 \%$ & $0.2 \%$ & $0.3 \%$ & $0.4 \%$ & $0.5 \%$ & $0.6 \%$ & $0.7 \%$ & $0.8 \%$ \\
\hline E.Coli O157:H7 & - & - & - & - & + & + & + & NT & NT & NT \\
\hline Staphylococcus & - & - & - & - & - & - & + & NT & NT & NT \\
\hline Salmonella & - & - & - & - & + & + & + & NT & NT & NT \\
\hline $\begin{array}{l}\text { Listeria } \\
\text { Monocytogens }\end{array}$ & - & - & - & - & - & - & - & - & - & + \\
\hline Bacillus Cereus & - & - & - & - & - & - & - & - & - & + \\
\hline
\end{tabular}

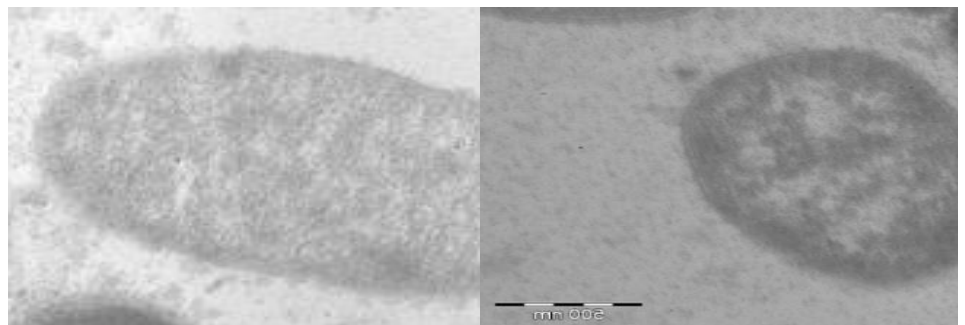

Figure 4a

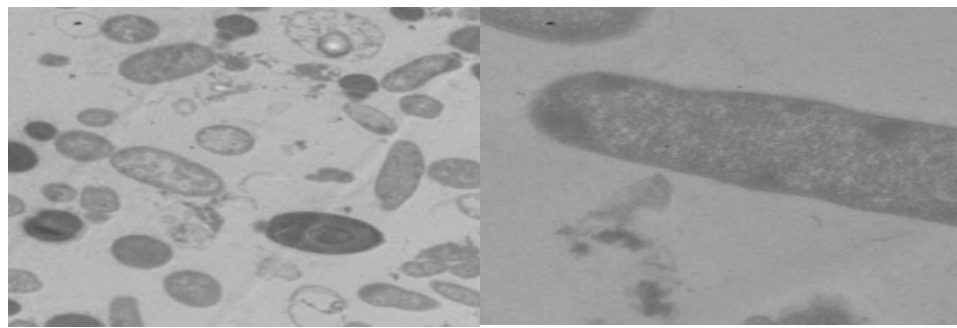

Figure 4c
From the results obtained in Table (4) it is clear that lower concentration was used against $E$. coli because the first used concentration $(0.03 \%)$ was inhibitory in the first trial, so it was a must to find out the maximum noninhibitory concentration. The results shown in (Figures 4a \& 4d) illustrated the intact cell wall of Salmonella in control suspension. It is also clear that all cell and components are present inside the cytoplasm without any leakage or perforation in the cell wall.

\section{Figures from 4a-4d the intact cell wall of the bacteria in control suspension}

(Figures 5a \& 5d) illustrated the effect of Thyme oil extract on the cell of Salmonella suspension. It is clear that the empty areas inside the cells exposed to the oil extracts which demonstrate the degeneration of most of the cytoplasmic constituents are predominant in most of the cells under investigation. Also, miss shapes of many bacterial cells are clear beside the disruption of the cell wall and leakage of its content. 


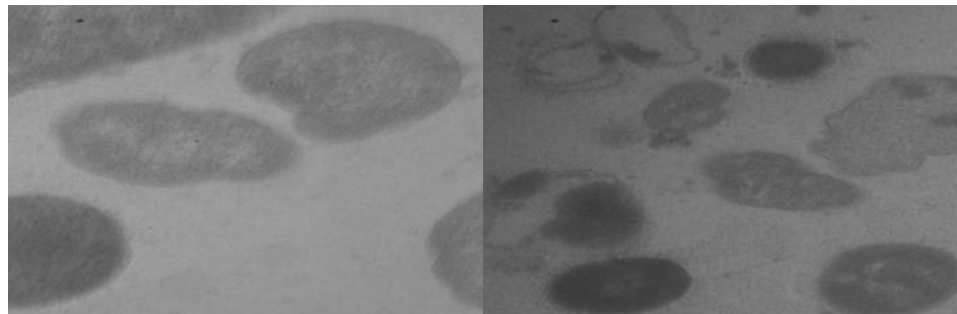

Figure 5a

Figure 5b

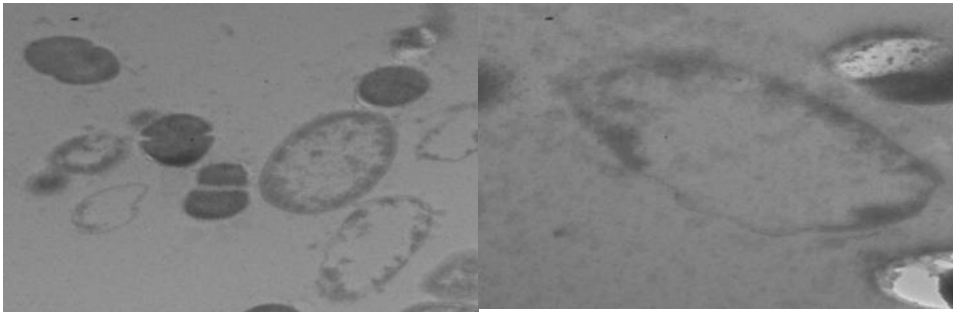

Figure 5c

Figure 5d

Figures from (5a-5d): The effect of Thyme oil extract on the cell of Salmonella Typhimurium suspension

The results in Figures $6 a \& 6 d$ showed the effect of Oregano oil extract on Salmonella Typhimurium cells. The shape of examined cells showed infirmity, evacuation from its constituents, and rupture of the cell membrane which caused leakage of the cytoplasm with its content.

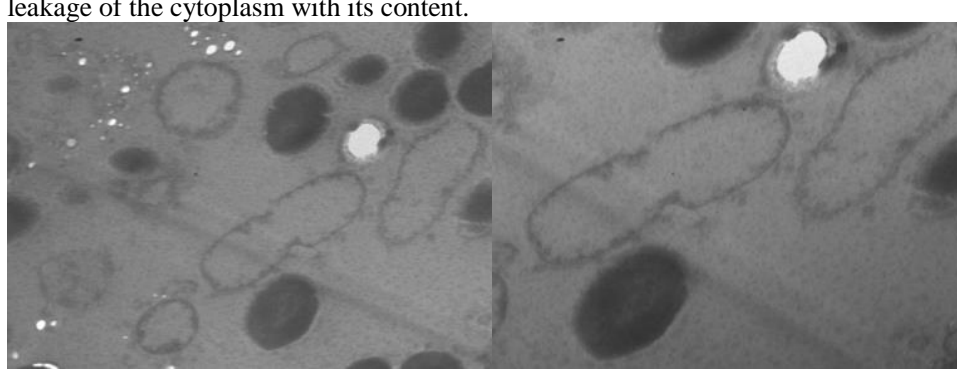

Figure 6a

Figure 6b

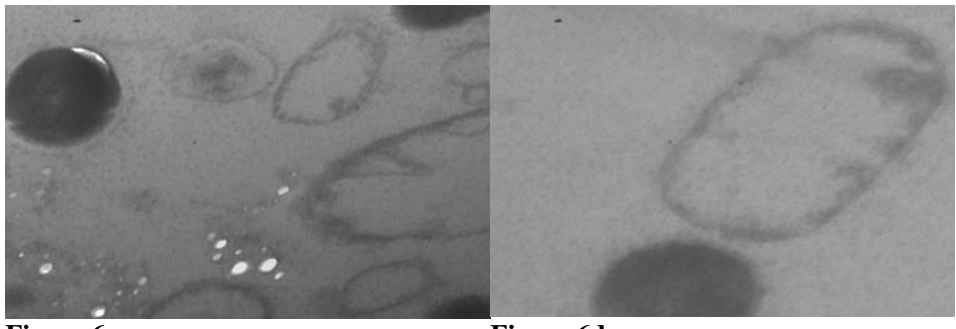

Figure 6c

Figure 6d
Figures 6a-6d the effect of Oregano oil extract on Salmonella typhimurium cells.

Furthermore, the results in Figures 7a \& 7f illustrated the effect of Menthol oil extract on the shape, structure, cytoplasmic content and cell wall. Emptying the cells of their content is very clear in most figures and the rupture of the cell wall is obvious as well.

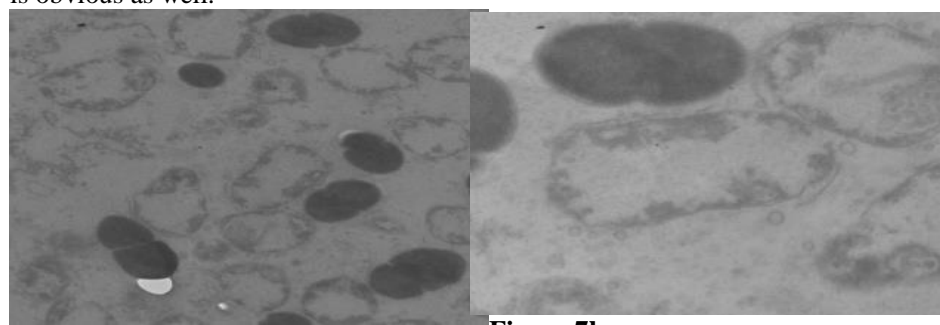

Figure 7a

Figure 7b

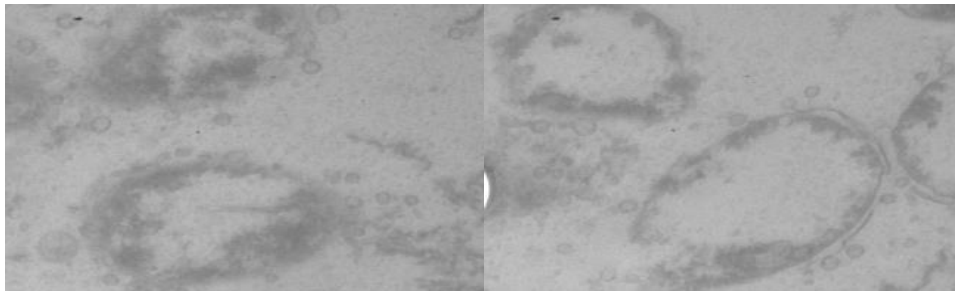

Figure 7c

\section{Figure 7d}

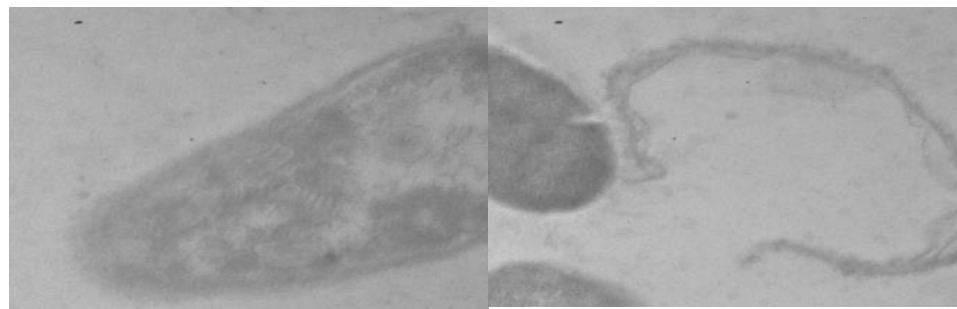

Figure 7e

Figure 7f

Figures (7a-7f): The effect of Menthol oil extract on salmonella Typhimurium cells.

The data in Table (6) illustrated the effect of the selected MICs of the used oil extracts on Total Bacterial Count during the storage period (14 days) and compares it with that obtained in the non-treated luncheon portion. It is clear from the obtained data that, in 3 days, Total Bacterial Count values in $T_{1}$ and $T_{2}$ were the same as that of $\mathrm{T}_{0}$ which showed $2 \operatorname{logs}$ higher than that of $\mathrm{T}_{0}$, while $\mathrm{T}_{4}$, $\mathrm{T}_{5}$, and $\mathrm{T}_{6}$ showed one $\log$ lower than that of $\mathrm{T}_{0}$.

Table 6 Effect of the selected MICs of the used oil extracts on total bacterial count (cfu/g) during storage period (14 days) and its comparison with that obtained in the non-treated luncheon portion

\begin{tabular}{|c|c|c|c|c|c|c|c|c|c|}
\hline $\begin{array}{l}\text { Sample } \\
\text { NO. }\end{array}$ & $\begin{array}{l}\text { Before Mixing } \\
\text { and process }\end{array}$ & $\begin{array}{l}\text { Before processing } \\
\text { after Mixing }\end{array}$ & After $p$ & ocessing & & & & & \\
\hline & & & Od & 1d & 3d & $5 d$ & $7 d$ & 9d & 14d \\
\hline Standard & $19 \times 10^{6}$ & -------- & $38 \times 10$ & $20 \times 10$ & $15 \times 10$ & $30 \times 10^{3}$ & $33 \times 10^{3}$ & $11 \times 10^{6}$ & $48 \times 10^{6}$ \\
\hline $\mathrm{T} 2$ & $19 \times 10^{6}$ & $48 \times 10^{6}$ & $90 \times 10$ & $4 \times 10$ & $30 \times 10$ & $48 \times 10^{4}$ & $60 \times 10^{6}$ & $40 \times 10^{6}$ & $56 \times 10^{6}$ \\
\hline T3 & $19 \times 10^{6}$ & $32 \times 10^{6}$ & $90 \times 10$ & $15 \times 10^{2}$ & $69 \times 10^{3}$ & $12 \times 10^{6}$ & $96 \times 10^{6}$ & $66 \times 10^{6}$ & $55 \times 10^{6}$ \\
\hline $\mathrm{T} 4$ & $19 \times 10^{6}$ & $10 \times 10^{6}$ & ND & $4 \times 10$ & $10 \times 10$ & $38 \times 10^{5}$ & $69 \times 10^{5}$ & $12 \times 10^{6}$ & $88 \times 10^{6}$ \\
\hline T6 & $19 \times 10^{6}$ & $37 \times 10^{6}$ & $10 \times 10$ & $5 \times 10$ & $2 \times 10$ & $6 \times 10$ & $5 \times 10$ & $7 \times 10$ & $30 \times 10^{3}$ \\
\hline
\end{tabular}

During the 5 days of storage, Total Bacterial Count was significantly higher in $\mathrm{T}_{3}$ and $\mathrm{T}_{4}$ when compared with that obtained in $\mathrm{T}_{0}$, but all were within the permissible level according to Egyptian standards (maximum $10^{4} \mathrm{cfu} / \mathrm{g}$ ).

On the other hand, during the 7 days of storage, the most effective treatments were $T_{1}$ which gave the same value as that of $T_{0}$ and $T_{6}$ with two logs lower than that of $\mathrm{T}_{0}$. The values obtained in $\mathrm{T}_{4}$ was one $\log$ higher than that obtained in $\mathrm{T}_{0}$ but sill within the permissible limit according to Egyptian standards but the values obtained in $\mathrm{T}_{2} \mathrm{~T}_{3}$ and $\mathrm{T}_{4}$ were higher than that obtained in $\mathrm{T}_{0}$ and exceeded the permissible limit according to Egyptian standards. In the 9 and 14 days of storage, all TPC values in all treatments exceeded the threshold value except that of T6 which continued within the permitted values.

The data in Table (7) showed that processing conditions could totally eliminate coliform bacteria which are indicated by the absence of TCC at 0 time. After 5 days, TCC could be detected in all treatments except $\mathrm{T}_{5}$ and $\mathrm{T}_{6}$ which stayed free till the end of the storage period. The presence of TCC after this period indicated that the processing procedure caused just injury for coliform bacteria. Injured bacteria could not be discovered during the first period of storage; they were discovered after re-enrichment by using the nutrients present in the matrix where. it could be cultured and counted. Only the behavior of coliform bacteria in T4 
was similar to that of $\mathrm{T}_{0}$ till the $9^{\text {th }}$ day of storage after which the count of

of $\mathrm{T}_{0}$. coliform bacteria in all treatments (except $\mathrm{T}_{5}$ and $\mathrm{T}_{6}$ ) increased compared to that

Table 7 Effect of the selected MICs of the used oil extracts on total coliform count (cfu/g) during storage period (14 days) and its comparison with that obtained in the non-treated luncheon portion

\begin{tabular}{|c|c|c|c|c|c|c|c|c|c|}
\hline \multirow{2}{*}{$\begin{array}{l}\text { Sample } \\
\text { NO. }\end{array}$} & \multirow{2}{*}{$\begin{array}{l}\text { Before Mixing } \\
\text { and process }\end{array}$} & \multirow{2}{*}{$\begin{array}{l}\text { Before } \\
\text { processing after } \\
\text { Mixing }\end{array}$} & \multicolumn{7}{|c|}{ After processing } \\
\hline & & & Od & 1d & 3d & $5 d$ & $7 d$ & 9d & $14 d$ \\
\hline Standard & $70 \times 10^{4}$ & ------- & ND & ND & ND & $10 \times 10$ & $4 \times 10$ & $40 \times 10$ & $20 \times 10$ \\
\hline $\mathrm{T} 1$ & $70 \times 10^{4}$ & $77 \times 10^{4}$ & ND & ND & ND & $25 \times 10$ & $69 \times 10^{2}$ & $37 \times 10^{3}$ & $34 \times 10^{3}$ \\
\hline $\mathrm{T} 2$ & $70 \times 10^{4}$ & $45 \times 10^{4}$ & ND & ND & $\mathrm{ND}$ & $4 \times 10$ & $22 \times 10^{2}$ & $15 \times 10^{3}$ & $5 \times 10^{3}$ \\
\hline T3 & $70 \times 10^{4}$ & $10 \times 10^{4}$ & ND & ND & $2 \times 10$ & $36 \times 10^{3}$ & $46 \times 10^{3}$ & $36 \times 10^{3}$ & $93 \times 10^{3}$ \\
\hline $\mathrm{T} 4$ & $70 \times 10^{4}$ & $86 \times 10^{4}$ & ND & ND & ND & $98 \times 10$ & $60 \times 10$ & $54 \times 10$ & $70 \times 10^{2}$ \\
\hline $\mathrm{T} 5$ & $70 \times 10^{4}$ & $74 \times 10^{4}$ & ND & ND & ND & ND & ND & ND & ND \\
\hline T6 & $70 \times 10^{4}$ & $11 \times 10^{4}$ & ND & ND & ND & ND & ND & ND & ND \\
\hline
\end{tabular}

The results in Table (8) showed that all Faecal coliform, which was present in completely eliminated after mixing and processing which was clear from the minced meat and all ingredients after mixing and before processing, was negative results obtained in the storage period as a whole.

Table 8 Effect of the selected MICs of the used oil extracts on Faecal Coliform Count (cfu/g) during storage period (14 days) and its comparison with that obtained in the non-treated luncheon portion.

\begin{tabular}{|c|c|c|c|c|c|c|c|c|c|}
\hline \multirow{2}{*}{ Sample NO. } & \multirow{2}{*}{$\begin{array}{l}\text { Before } \\
\text { Mixing } \\
\text { process } \\
\end{array}$} & \multirow{2}{*}{$\begin{array}{l}\text { Before } \\
\text { processing } \\
\text { after Mixing }\end{array}$} & \multicolumn{7}{|c|}{ After processing } \\
\hline & & & Od & $1 d$ & 3d & $5 d$ & 7d & 9d & 14d \\
\hline Standard & $14 \times 10^{3}$ & NT & ND & ND & ND & ND & ND & ND & ND \\
\hline T1 & $14 \times 10^{3}$ & $10 \times 10^{3}$ & $\mathrm{ND}$ & ND & ND & ND & $\mathrm{ND}$ & $\mathrm{ND}$ & $\mathrm{ND}$ \\
\hline T2 & $14 \times 10^{3}$ & $10 \times 10^{2}$ & ND & ND & ND & ND & ND & ND & ND \\
\hline T3 & $14 \times 10^{3}$ & $36 \times 10^{2}$ & ND & ND & ND & ND & ND & ND & ND \\
\hline T4 & $14 \times 10^{3}$ & $23 \times 10^{3}$ & ND & ND & ND & ND & $\mathrm{ND}$ & ND & $\mathrm{ND}$ \\
\hline T5 & $14 \times 10^{3}$ & $50 \times 10^{2}$ & ND & ND & ND & ND & ND & ND & ND \\
\hline T6 & $14 \times 10^{3}$ & $35 \times 10^{2}$ & ND & ND & ND & ND & ND & ND & ND \\
\hline
\end{tabular}

It is obvious from the obtained data that Staphylococcus spp. present before processing was eliminated in $\mathrm{T}_{1}, \mathrm{~T}_{4}$, and $\mathrm{T}_{5}$ at 0 time till the end of the experiment (Table 9).

Table 9 Effect of the selected MICs of the used oil extracts on Staphylococcus Count (cfu/g) during storage period (14 days) and its comparison with that obtained in the non-treated luncheon portion.

\begin{tabular}{|c|c|c|c|c|c|c|c|c|c|}
\hline Sample NO. & $\begin{array}{l}\text { Before } \\
\text { Mixing } \\
\text { and } \\
\text { process }\end{array}$ & $\begin{array}{l}\text { Before } \\
\text { processing } \\
\text { after } \\
\text { Mixing }\end{array}$ & After p & essing & & & & & \\
\hline & & & Od & 1d & 3d & 5d & $7 d$ & 9d & 14d \\
\hline Standard & $26 \times 10^{4}$ & NT & ND & $2 \times 10$ & $3 \times 10$ & ND & ND & ND & ND \\
\hline $\mathrm{T} 1$ & $26 \times 10^{4}$ & $10 \times 10^{4}$ & ND & ND & ND & ND & ND & ND & ND \\
\hline $\mathrm{T} 2$ & $26 \times 10^{4}$ & $50 \times 10^{3}$ & ND & ND & ND & $31 \times 10^{3}$ & $34 \times 10^{3}$ & $83 \times 10^{3}$ & $17 \times 10^{4}$ \\
\hline $\mathrm{T} 3$ & $26 \times 10^{4}$ & $40 \times 10^{3}$ & $29 \times 10$ & $36 \times 10$ & $55 \times 10$ & $10 \times 10^{3}$ & $10 \times 10^{4}$ & $13 \times 10^{4}$ & $50 \times 10^{3}$ \\
\hline $\mathrm{T} 4$ & $26 \times 10^{4}$ & $10 \times 10^{4}$ & ND & ND & ND & ND & ND & ND & ND \\
\hline T5 & $26 \times 10^{4}$ & $46 \times 10^{3}$ & ND & ND & ND & ND & ND & ND & ND \\
\hline T6 & $26 \times 10^{4}$ & $20 \times 10^{3}$ & $2 \times 10$ & $1 \times 10$ & ND & ND & ND & ND & ND \\
\hline
\end{tabular}

In case of $\mathrm{T}_{3}$ the count was $2 \operatorname{logs}$ decreased and then it gradually increased to reach $10 \times 10^{3} \mathrm{CFU} / \mathrm{g}$ at 5 days, then $10^{3}, 10^{4}, 10^{4}$ and $10^{3} \mathrm{cfu} / \mathrm{g}$ at $5,7,9$ and 14 of storage, respectively. Injured Staphylococcus were re-enriched in $\mathrm{T}_{0}, \mathrm{~T}_{2}$, and $\mathrm{T}_{6}$ but then were completely absent on the $5^{\text {th }}$ day in $\mathrm{T}_{0}$ and $\mathrm{T}_{2}$ on the $3^{\text {rd }}$ day of storage in $\mathrm{T}_{6}$.

The data obtained indicated that Bacillus cereus, Salmonella spp. and molds were not present from the start until the end of the experiment (Table 10).

Table 10 Effect of the selected MICs of the used oil extracts on Bacillus cereus, Salmonella spp. and total fungal count during storage period (14 days) and its comparison with that obtained in the non-treated luncheon portion.

\begin{tabular}{|c|c|c|c|c|c|c|c|c|c|}
\hline \multirow{2}{*}{ Sample NO. } & \multirow{2}{*}{$\begin{array}{l}\text { Before } \\
\text { Mixing and } \\
\text { process }\end{array}$} & \multirow{2}{*}{$\begin{array}{l}\text { Before } \\
\text { processing } \\
\text { after Mixing }\end{array}$} & \multicolumn{7}{|c|}{ After processing } \\
\hline & & & Od & 1d & 3d & $5 d$ & $7 d$ & 9d & $14 d$ \\
\hline Standard & ND & NT & ND & ND & ND & ND & $\mathrm{ND}$ & ND & ND \\
\hline $\mathrm{T} 1$ & ND & ND & ND & ND & ND & ND & ND & ND & ND \\
\hline $\mathrm{T} 2$ & ND & ND & ND & ND & ND & ND & ND & ND & ND \\
\hline $\mathrm{T} 3$ & ND & ND & ND & ND & ND & ND & ND & ND & ND \\
\hline $\mathrm{T} 4$ & ND & ND & ND & ND & ND & ND & ND & ND & ND \\
\hline T5 & ND & ND & ND & ND & ND & ND & ND & ND & ND \\
\hline T6 & ND & ND & ND & ND & ND & ND & ND & ND & ND \\
\hline
\end{tabular}

The data Table (11) showed that Total Yeast Count had the same behavior obtained by FCC as micro flora present in non-processed mixed ingredients was completely eliminated after processing and no injured cells were noticed throughout the time of storage. 
Table 11 Effect of the selected MICs of the used oil extracts on total yeast count (cfu/g) during storage period (14 days) and its comparison with that obtained in the non-treated luncheon portion.

\begin{tabular}{|c|c|c|c|c|c|c|c|c|c|}
\hline \multirow[t]{2}{*}{ Sample NO. } & \multirow{2}{*}{$\begin{array}{l}\text { Before } \\
\text { Mixing and } \\
\text { process }\end{array}$} & \multirow{2}{*}{$\begin{array}{l}\text { Before } \\
\text { processing } \\
\text { after Mixing }\end{array}$} & \multicolumn{7}{|c|}{ After processing } \\
\hline & & & od & 1d & 3d & $5 d$ & $7 d$ & 9d & $14 d$ \\
\hline Standard & $68 \times 10^{4}$ & NT & ND & ND & ND & ND & ND & ND & $\mathrm{D}$ \\
\hline $\mathrm{T} 1$ & $68 \times 10^{4}$ & $66 \times 10^{4}$ & ND & ND & ND & ND & ND & ND & ND \\
\hline $\mathrm{T} 2$ & $68 \times 10^{4}$ & $13 \times 10^{4}$ & ND & ND & ND & ND & ND & ND & ND \\
\hline $\mathrm{T} 3$ & $68 \times 10^{4}$ & $28 \times 10^{4}$ & ND & ND & ND & ND & ND & ND & ND \\
\hline $\mathrm{T} 4$ & $68 \times 10^{4}$ & $88 \times 10^{4}$ & ND & ND & ND & ND & ND & ND & ND \\
\hline $\mathrm{T} 5$ & $68 \times 10^{4}$ & $80 \times 10^{4}$ & ND & ND & ND & ND & $\mathrm{ND}$ & ND & ND \\
\hline T6 & $68 \times 10^{4}$ & $21 \times 10^{4}$ & ND & ND & ND & ND & ND & ND & ND \\
\hline
\end{tabular}

The data obtained and illustrated in Figure 8 showed the panel test results of luncheon with different compositions (Table 12). Figure (8) Template of Panel test Score sheet:

\begin{tabular}{|l|l|l|l|l|l|l|l|}
\hline $\begin{array}{l}\text { Sample No. } \\
\text { Items }\end{array}$ & control & 1 & 2 & 3 & 4 & 5 & 6 \\
\hline Color & & & & & & & \\
\hline smell & & & & & & & \\
\hline Texture & & & & & & & \\
\hline Taste & & & & & & & \\
\hline
\end{tabular}

Template of comparison score sheet:

\begin{tabular}{|l|l|l|}
\hline Sample NO. & $\begin{array}{l}\text { There is } \\
\text { a difference }\end{array}$ & $\begin{array}{l}\text { There is } \\
\text { No difference }\end{array}$ \\
\hline 1 & & \\
\hline 2 & & \\
\hline 3 & & \\
\hline 4 & & \\
\hline 5 & & \\
\hline 6 & & \\
\hline
\end{tabular}

Table 12 Statistical analysis of panel test results of luncheon with different compositions.

\begin{tabular}{lllll}
\hline \multicolumn{5}{c}{ Parameters } \\
Groups & Color & smell & Texture & Taste \\
\hline Standard & $2.9^{\mathrm{a}} \pm 0.31$ & $2.7^{\mathrm{a}} \pm 0.33$ & $2.9^{\mathrm{a}} \pm 0.27$ & $2.8^{\mathrm{ab}} \pm 0.29$ \\
\hline $\mathbf{2}$ & $2.4^{\mathrm{a}} \pm 0.22$ & $2.2^{\mathrm{a}} \pm 0.29$ & $2.6^{\mathrm{a}} \pm 0.16$ & $1.7^{\mathrm{cd}} \pm 0.33$ \\
\hline $\mathbf{3}$ & $2.9^{\mathrm{a}} \pm 0.31$ & $3.0^{\mathrm{a}} \pm 0.21$ & $2.8^{\mathrm{a}} \pm 0.29$ & $3.1^{\mathrm{a}} \pm 0.31$ \\
\hline $\mathbf{4}$ & $2.6^{\mathrm{a}} \pm 0.26$ & $2.2^{\mathrm{a}} \pm 0.38$ & $2.4^{\mathrm{a}} \pm 0.30$ & $0.9^{\mathrm{de}} \pm 0.37$ \\
\hline $\mathbf{5}$ & $2.9^{\mathrm{a}} \pm 0.17$ & $2.9^{\mathrm{a}} \pm 0.17$ & $2.4^{\mathrm{a}} \pm 0.26$ & $2.0^{\mathrm{bc}} \pm 0.25$ \\
\hline $\mathbf{6}$ & $3.2^{\mathrm{a}} \pm 0.20$ & $3.0^{\mathrm{a}} \pm 0.25$ & $2.8^{\mathrm{a}} \pm 0.24$ & $3.3^{\mathrm{a}} \pm 0.26$ \\
\hline $\mathbf{7}$ & $3.0^{\mathrm{a}} \pm 0.25$ & $2.1^{\mathrm{a}} \pm 0.43$ & $2.5^{\mathrm{a}} \pm 0.30$ & $0.5^{\mathrm{e}} \pm 0.22$ \\
\hline
\end{tabular}

Mean values are expressed as means \pm SE.

Means with different superscript letters in the column are significantly different at $\mathrm{P}<0.05$

It was clear that no significant changes were observed neither in color, smell or texture. Also, it was noticed that the ingredients containing oregano $\left(T_{2}\right.$ and $\left.T_{5}\right)$ had the most acceptable taste of luncheon. It was also obvious that T3 and T6 were not accepted at all by all participants in this panel test.

\section{DISCUSSION}

Because using essential oils are the most recent approach for food preservation due to their natural, safe, affordable and environmental friendly substances, many trials were conducted to study their compositions, modes of action and the antimicrobials positive effects on the shelf lifetime. In this study, qualitative analysis of Oregano, Thyme, and Menthol revealed that Carvacrol and Thymol were the most predominant active ingredients in Thyme and Oregano, while Menthone and its derivatives were the most predominant ones in case of Menthol. This finding was in agreement with(Alankar, 2009) and (OrtegaNieblas et al., 2011) who found that carvacrol, Thymol, and Menthone were the most predominant active ingredients in Thyme, Oregano and Menthol, respectively. The obtained MICs of Thyme $0.3 \%$, Oregano $0.1 \%$, and Menthol $0.8 \%$ were recommended to be used in the preparation of luncheon as these concentrations inhibited the visible growth of Bacillus cereus bacteria which was chosen to be the model for the most resistant strain due to its thick wall and spore-forming capability. This finding agreed with that reached by (REYESJURADO, LOPEZ-MALO, \& PALOU, 2016) who determined the MIC of Oregano against food-borne pathogens, and their results ranged from 0.05 to $0.5 \%$. (Miladi et al., 2013) found the MIC of Thyme ranging between 0.78 to $3.12 \mathrm{mg} / \mathrm{ml}$, whereas (Tyagi \& Malik, 2011) found the results of MIC of Menthol ranging between 1.13 to $2.25 \mathrm{mg} / \mathrm{ml}$. Using Menthol in a concentration of $0.8 \%$ was performed to control all types of pathogens including spore-forming ones as they have the capability to resist lower concentrations through the effect of their thick cell wall and/or the spore-forming nature. This finding was supported by that reported by (Boskovic et al., 2015) who stated that essential oils showed a great inhibitory effect against spore-forming bacteria in higher concentrations. Using the obtained MICs of choice in luncheon preparation with the complete or partial replacement of sodium nitrite showed a great result which will enable a big positive improvement if used in the industry towards human health. The obtained results showed that using half of the recommended concentration of hazardous sodium nitrite with the obtained MICs of Thyme and menthol under study can be considered as effective as the commonly used concentration of sodium nitrite formula recommended by Codex alimentarious $(125 \mathrm{ppm})$ in preserving the luncheon product and keeping its microbial quality fit for consumption for 7 days. While in case of Menthol, the used concentration showed extended shelf life till 14 days of storage. This result was similar to that obtained by (Roller \& Seedhar, 2002), (Alankar, 2009),(Santana et al., 2013) and (Sakkas \& Papadopoulou, 2017) who concluded that using Thyme, oregano and menthol as preservatives has a significant effect against food poisoning bacteria and can extend the shelf lifetime of different food categories. The obtained photos which illustrated the mode of action of EOs under study against salmonella (as a model of a predominant and problematic food poisoning causative agent) supported the data reported by (Alankar, 2009) and (OrtegaNieblas et al., 2011), who concluded that essential oils cause impairment of the permeability of the cell wall of pathogenic bacteria and also impairment in the ion exchange and electrolyte exchange which led to rupture of the cell wall followed by loss of all cell constituents.

Results of the panel test showed that Oregano was the most acceptable preservative followed by thyme, while Menthol treated products were not accepted at all as the used concentration was very high. Further studies can be performed to study how to utilize the antimicrobial activity of Menthol in lower effective concentration.

It can be concluded from this work that Essential oils can be used as food preservatives which help to increase food safety parameters and decrease food loss in different categories and can reduce the health hazards of not only food poisoning bacteria but also the carcinogenic sodium nitrite.

\section{CONCLUSION}

It was concluded that Sodium nitrite can be completely or partially replaced by phytochemicals preservatives during luncheon processing to control food poisoning bacteria. Also, Transmission electron microscope can be considered an excellent tool to determine the antimicrobial effect of phytochemicals against food poisoning bacteria.

Acknowledgment: We would like to thank all members of Food Safety Department, Regional Center for Food and Feed, and Agriculture Research Center

\section{REFERENCES}

Alankar, S. (2009). A review on peppermint oil. Asian Journal of Pharmaceutical and Clinical Research, 2(2), 27-33.

Alvi, N. K., Rizvi, R. Y., \& Hadi, S. M. (1986). Interaction of quercetin with DNA. Bioscience Reports, 6(10), 861-868. https://doi.org/10.1007/bf01116239

Anand, S. P., \& Sati, N. (2013). Artificial Preservatives and Their Harmful Effects: Looking Toward Nature for Safer Alternatives. International Journal of Pharmaceutical Sciences and Research IJPSR, 4(7), 2496-2501. https://doi.org/10.13040/IJPSR.0975-8232.4(7).24960-01

Boskovic, M., Zdravkovic, N., Ivanovic, J., Janjic, J., Djordjevic, J., Starcevic, M., \& Baltic, M. Z. (2015). Antimicrobial Activity of Thyme (Tymus vulgaris) and Oregano (Origanum vulgare) Essential Oils against Some Food-borne Microorganisms. Procedia Food Science, 5(31034), 18-21. https://doi.org/10.1016/j.profoo.2015.09.005

Codex. (1981). STANDARD FOR LUNCHEON MEAT CODEX. 
INTERNATIONAL

FOOD

STANDARDS

89

https://doi.org/10.1017/CBO9781107415324.004

Faleiro, M. L. (2011). The mode of antibacterial action of essential oils. In A Méndez-Vilas (Ed.), Science against microbial pathogens: communicating current research and technological advances (Vol. 3). CFORMATEX.

Gantois, I., Eeckhaut, V., Pasmans, F., Haesebrouck, F., Ducatelle, R., \& Van Immerseel, F. (2008). A comparative study on the pathogenesis of egg contamination by different serotypes of Salmonella. Avian Pathology, 37(4), 399-406. https://doi.org/10.1080/03079450802216611

Gao, C., Tian, C., Lu, Y., Xu, J., Luo, J., \& Guo, X. (2011). Essential oil composition and antimicrobial activity of Sphallerocarpus gracilis seeds against selected food-related bacteria. Food Control, 22(3-4), 517-522. https://doi.org/10.1016/J.FOODCONT.2010.09.038

Mekonnen, A., \& Sisay, D. (2015). A Review on Major Food Borne Bacteria Illnesses. Journal of Tropical Diseases Journal of Tropical Diseases, 3(4). https://doi.org/DOI: 10.4176/2329-891X.1000176

Miladi, H., Slama, R. Ben, Mili, D., Zouari, S., Bakhrouf, A., Ammar, E., ... Ammar, E. (2013). Essential oil of \&amp;lt;i\&amp;gt;Thymus vulgaris\&amp;lt;/i\&amp;gt; L. and \&amp;lt;i\&amp;gt;Rosmarinus officinalis\&amp;lt;/i\&amp;gt; L.: Gas chromatography-mass spectrometry analysis, cytotoxicity and antioxidant properties and antibacterial activities against foodborne pathogens. Natural Science, 05(06), 729-739. https://doi.org/10.4236/ns.2013.56090

NMKL. (2004). Coliform bacteria. Detection in foods and feeds. Retrieved September 15, 2019, from 44, 6.ed. website https://www.nmkl.org/index.php/en/publications/item/koliforme-bakterierbestemmelse-i-naeringsmidler-og-for-nmkl-44-6-ed-2004

NMKL. (2005a). Mould and yeasts. Determination in foods and feed. Retrieved September 15, 2019, from 98, 4.Ed. website: https://www.nmkl.org/index.php/en/publications/item/nmkl-98

NMKL. (2005b). Thermotolerant coliform bacteria and Escherichia coli. Enumeration in food and feed. (. Retrieved September 15, 2019, from 125, 4. Ed. website: https://www.nmkl.org/index.php/en/publications/item/termotolerantekoliforme-bakterier-og-escherichia-coli-bestemmelse-i-naeringsmidler-og-fornmkl-125-4-utg-2005

NMKL. (2009). Coagulase positive staphylococci. Enumeration in foods. Retrieved September 15, 2019, from 66, 5.Ed website: https://www.nmkl.org/index.php/en/publications/item/koagulasepositivestafylokokker-bestemmelse-i-naeringsmidler-nmkl-66-5-ed-2009

NMKL. (2010). Presumptive Bacillus cereus. Determination in foods. Retrieved September 15, 2019, from 67, 6. Ed. website: https://www.nmkl.org/index.php/en/publications/item/presumptiv-bacilluscereus-bestemmelse-i-naeringsmidler-nmkl-67-6-ed-2010

NMKL. (2013). Aerobic microorganisms. Determination in foods at $37{ }^{\circ} \mathrm{C}, 30$ ${ }^{\circ} \mathrm{C}, 25{ }^{\circ} \mathrm{C}, 20{ }^{\circ} \mathrm{C}, 17 / 7{ }^{\circ} \mathrm{C}$ or $6.5{ }^{\circ} \mathrm{C}$ by the colony count method. Retrieved September 15, 2019, from (86, 5. Ed.) website: https://www.nmkl.org/index.php/en/publications/item/aerobe-mikroorgansimerbestemmelse-i-levnedsmidler-ved-37-c-30-c-25-c-20-c-17-7-c-eller-65-c-efterkolonitalsmetoden-nmkl-86-5-utg-2013

Ortega-Nieblas, M. M., Robles-Burgueño, M. R., Acedo-Félix, E., GonzálezLeón, A., Morales-Trejo, A., \& Vázquez-Moreno, L. (2011). Revista fitotecnia mexicana publicada por la Sociedad Mexicana de Fitogenética. In Revista
Fitotecnia
Mexicana.
Retrieved
from

https://investigadores.unison.mx/en/publications/chemical-composition-and-

antimicrobial-activity-of-oregano-lippia

REYES-JURADO, F., LÓPEZ-MALO, A., \& PALOU, E. (2016). Antimicrobial Activity of Individual and Combined Essential Oils against Foodborne Pathogenic Bacteria. Journal of Food Protection, 79(2), 309-315 https://doi.org/10.4315/0362-028X.JFP-15-392

Roller, S., \& Seedhar, P. (2002). Carvacrol and cinnamic acid inhibit microbial growth in fresh-cut melon and kiwifruit at $4^{\circ}$ and $8^{\circ} \mathrm{C}$. Letters in Applied Microbiology, 35(5), 390-394. https://doi.org/10.1046/j.1472 765X.2002.01209.x

Sakkas, H., \& Papadopoulou, C. (2017). Antimicrobial Activity of Basil, Oregano, and Thyme Essential Oils. Journal of Microbiology and Biotechnology, 27(3), 429-438. https://doi.org/10.4014/jmb.1608.08024

Santana, P. M., Miranda, M., Payrol, J. A., Silva, M., Hernández, V., \& Peralta E. (2013). Gas Chromatography-Mass Spectrometry Study from the Leaves Fractions Obtained of Vernonanthura patens (Kunth) H. Rob. International Journal of Organic Chemistry, (3), 105-109. https://doi.org/10.4236/ijoc.2013.32011

Senhaji, O., Faid, M., \& Kalalou, I. (2007). Inactivation of Escherichia coli O157:H7 by essential oil from Cinnamomum zeylanicum. Brazilian Journal of Infectious Diseases, 11(2), 234-236. https://doi.org/10.1590/S1413$\underline{86702007000200013}$

Sharma, S. (2015). Food Preservatives and their Harmfull Effect. International Journal of Scientific and Research Publications, 5(4), 5-6. Retrieved from www.ijsrp.org

Tyagi, A. K., \& Malik, A. (2011). Antimicrobial potential and chemica composition of Eucalyptus globulus oil in liquid and vapour phase against food spoilage microorganisms. Food Chemistry, 126(1), 228-235. https://doi.org/10.1016/j.foodchem.2010.11.002

WHO. (2007). WHO: Food safety and foodborne illness.Fact sheets No. 237. Geneva. (March). Retrieved from https://foodhygiene2010.files.wordpress.com/2010/06/who-food safety fact$\underline{\text { sheet.pdf }}$ 